\title{
The Underwater Photic Environment of Two Subarctic Icelandic Lakes
}

\author{
P.H. HEINERMANN ${ }^{1}$ and M.A. ALI ${ }^{2}$
}

(Received 16 July 1991; accepted in revised form 15 June 1992)

\begin{abstract}
The underwater light fields of two Icelandic lakes of volcanic origin and differing trophic status, Thingvallavatn (oligotrophic) and Myvatn (eutrophic), were investigated. Gilvin and turbidity depth profiles were also measured. Diurnal variation in photosynthetically active radiation (PAR) reached almost 3 orders of magnitude. Downward irradiance spectra were variable near the surface, but with increases in depth transmission peaks at 510, 560 and 570 nanometres $(\mathrm{nm})$ became apparent in Thingvallavatn, Myvatn-East Basin and Myvatn-South Basin respectively. Upward irradiance transmission maxima shifted from 480 to $500 \mathrm{~nm}$ with depth in Thingvallavatn, while in Myvatn they remained near $570 \mathrm{~nm}$. An irradiance trough at $520 \mathrm{~nm}$ was noted in both the upward and downward spectra of Thingvallavatn. The importance of phytoplankton (chlorophyll) and gilvin in modifying the underwater light climate of Myvatn is clearly demonstrated. The mean downwelling and upwelling irradiance curves for Thingvallavatn coincide very well with the spectral sensitivities of resident adult arctic charr. This provides support for the sensitivity hypothesis.
\end{abstract}

Key words: subarctic, limnology, irradiance, underwater light, arctic charr, spectral sensitivity, Iceland

RÉSUMÉ. L'environnement photique sous-marin de deux lacs islandais, le Thingvallavatn (oligotrophe) et le Myvatn (eutrophe), d'origine volcanique et présentant un état trophique différent, ont été étudiés. La quantité de matière organique dissoute (gilvin) et la turbidité ont été mesurées en fonction de la profondeur dans chaque lac. La radiation disponible pour la photosynthèse (PAR) pouvait varier quotidiennement jusqu'à trois ordres de grandeur. Alors que les spectres de l'irradiance descendante variaient près de la surface, ils augmentaient avec la profondeur aux pics de transmission de 510, 560 et 570 nanometres $(\mathrm{nm})$ respectivement dans le Thingvallavatn et le bassin est du Myvatn et le bassin sud du Myvatn. Les maxima dans la transmission de l'irradiance ascendante ont été décalés avec la profondeur de 480 à $500 \mathrm{~nm}$ dans le Thingvallavatn tandis que dans le Myvatn ils sont demeurés près de $570 \mathrm{~nm}$. Une zone d'absorption à $520 \mathrm{~nm}$ a également été observée dans les spectres descendants et ascendants du Thingvallavatn. L'importance du phytoplancton (chlorophylle) et de la matière organique dissoute (gilvin) dans la modification de l'environnement photique sous-marin du Myvatn a été nettement démontrée. Les spectres moyens de l'irradiance descendante et ascendante coïncident très étroitement avec les sensibilités spectrales chez les ombles-chevaliers adultes indigènes. Ceci appuie l'hypothèse de la sensibilité chez ces poissons.

Mots clés: subarctique, limnologie, irradiance, lumière sous-marine, omble-chevalier, sensibilité spectrale, Islande

\section{INTRODUCTION}

The underwater photic environments of fresh waters have been shown to be quite variable, such that the quantity and quality of light transmission may change both temporally and spatially (Smith et al., 1973; Kirk, 1977a; Eloranta, 1978; Roemer and Hoagland, 1979; Dubinsky and Berman, 1979; Bowling et al., 1986; Heinermann and Ali, 1988; Chambers and Prepas, 1988). In spite of these fluctuations a crude optical classification for inland water has been presented by Kirk (1980). It is based upon the relative contributions of gilvin (dissolved organic matter), tripton (inorganic particulates), algae and the water itself to the absorption of underwater quanta. Fresh waters may then have their light fields categorized as being influenced primarily by one or more of these factors. Scattering, though not included in this classification, may also be very important in affecting the amount and at times the spectral distribution of the light passing through the water column (Kirk, 1983, 1985, 1989). These modifications to the underwater light field brought about by absorptive and scattering processes have biological importance for the organisms present. Algal productivity and species composition may be altered (Talling, 1971; Kirk, 1976; Eloranta, 1978; Kirk, 1979; Jeffrey, 1980; Kirk, 1981), zeitgebers (triggering stimuli) may be provided for diel zooplankton migrations (Siebeck, 1960; Ringelberg, 1964) and visual tasks of other aquatic animals, such as fish, may also be affected (Barlow, 1974; McFarland and Munz, 1975; Lythgoe, 1979; Levine et al., 1980; Dabrowski and Jewson, 1984; Guthrie, 1986; Lythgoe, 1987; Munk et al., 1989).

With this latter aspect in mind, we set out to characterize the underwater photic environments of two of Iceland's largest lakes, Thingvallavatn and Myvatn. These volcanic lakes are a valuable addition to a continuing survey of lakes at different latitudes and of differing trophic states (Heinermann, 1986; Heinermann and Ali, 1988; Heinermann et al., 1990). As well, a detailed investigation of the underwater light in these lakes is lacking, even though most other aspects of the ecosystems of Thingvallavatn and Myvatn have been studied (Antonsson, 1977; Jónasson, 1979; Lindegaard, 1980; Snorrason, 1982; Lastein, 1983; Jónsson, 1987; Jónasson and Lindegaard, 1988; Jonsson et al. , 1988; Gardarsson et al., 1988). These data were collected in conjunction with a concurrent study by the authors on the visual abilities of the resident arctic charr in Thingvallavatn. As such, they form a critical framework within which the visual task and response of these charr can be investigated.

The primary objective of this study was therefore to characterize the underwater light fields of two neo-volcanic subarctic lakes, Thingvallavatn and Myvatn. With this information and the existing spectral sensitivity data for the vision of resident arctic charr, we will determine whether they are well adapted to their photic environment. This investigation is part of the continuing Thingvallavatn and Myvatn projects that began in 1971 and focus upon the functioning and dynamic ecology of North Atlantic ridge lakes.

\section{SITE DESCRIPTION}

Thingvallavatn, the largest lake in Iceland, is located in the southwest $\left(64^{\circ} 6^{\prime} \mathrm{N}, 21^{\circ} 8^{\prime} \mathrm{W}\right)$ at $100.7 \mathrm{~m}$ above sea level (Fig. 1A). It has a surface area of $83.7 \mathrm{~km}^{2}$, a maximum depth of $114 \mathrm{~m}$ and a mean depth of $34.1 \mathrm{~m}$ (Rist, 1975). The primary inflow $(70-90 \%)$ is subterranean, entering the lake near the

'Department of Biology, University of Ottawa, 30 Marie Curie, Ottawa, Ontario, Canada K1N 6N5

2Département de Sciences biologiques, Université de Montréal, Case postale 6128, Succursale A, Montrél, Québec, Canada H3C 3J7; offprint requests to: M.A. Ali

(C)The Arctic Institute of North America 

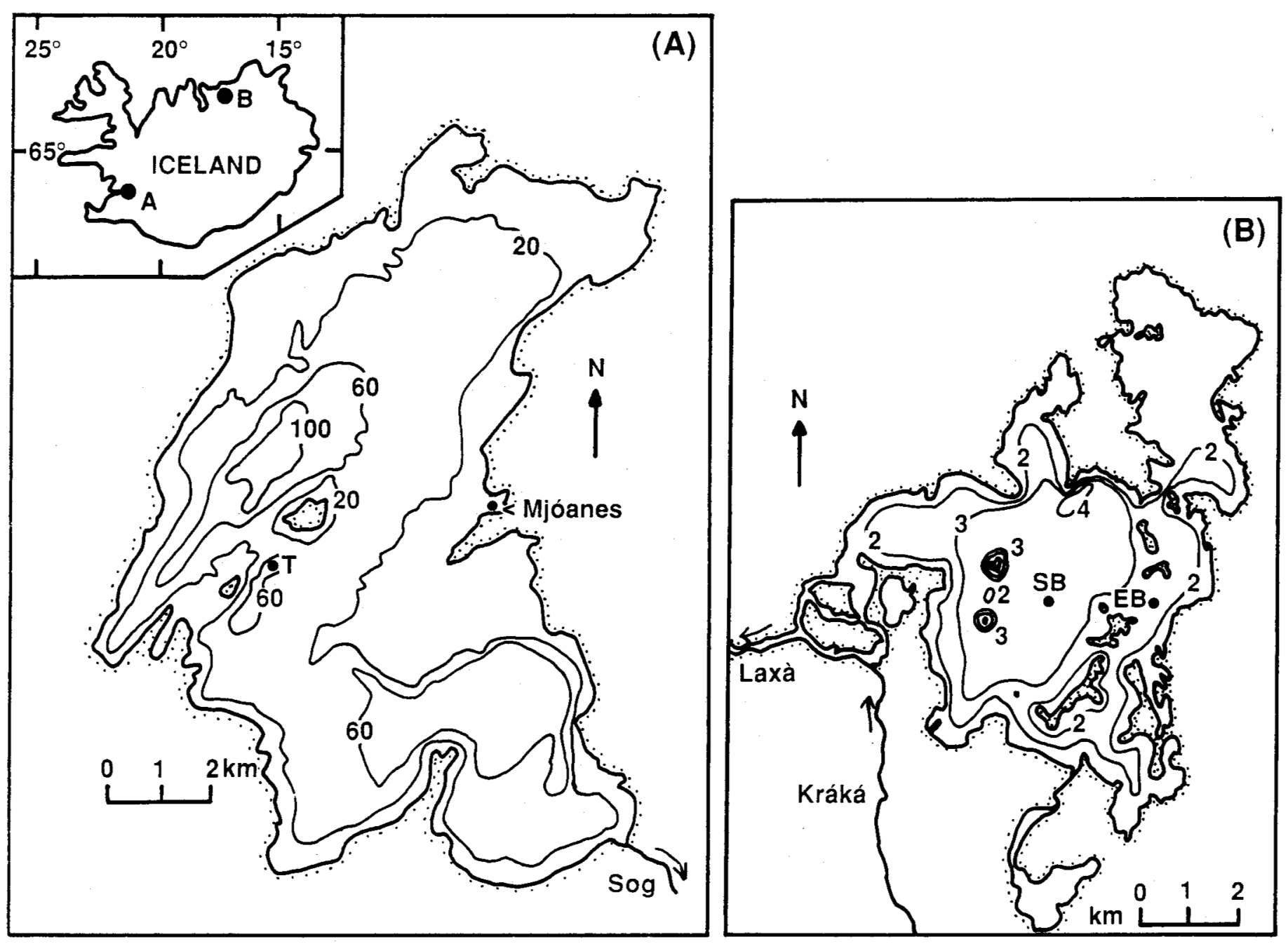

FG. 1. Bathymetric maps of (A) Thingvallavatn and (B) Myvatn. Sampling locations for Thingvallavatn were $T$ (irradiance profiles) and Mjoanes (diurnal variation); those for Myvatn were SB (south basin) and EB (east basin). In (A) 20,60 and $100 \mathrm{~m}$ contours are shown; in (B) 2, 3 and $4 \mathrm{~m}$ contours are presented. Inset shows their location in Iceland.

northern and eastern shoreline through porous rocks in the catchment area (Arnason, 1976). As a result, water chemistry, levels and temperatures are quite stable both seasonally and yearly. The formation and continued modification of the lake basin have been due to the combined effects of glacial and tectonic activity (Saemundsson, 1976). Thingvallavatn may be classified as a dimictic oligotrophic lake (a nutrient-poor lake that mixes completely twice a year). Accordingly, phytoplankton gross production averaged $70 \mathrm{gC} \cdot \mathrm{m}^{-2} \cdot \mathrm{yr}^{-1}$ over the period 1975-82 (Lastein, 1983; Kairesalo et al., 1989). The very large pelagic zone contains a somewhat simple zooplankton community (Antonsson, 1977), while the littoral zone is home to a diverse invertebrate community (Lindegaard, 1980; Snorrason, 1982). Arctic charr (Salvelinus alpinus) and the three spine stickleback (Gasterosteus aculeatus) are the most abundant fish species found, while a few brown trout (Salmo trutta) are also present. Four very distinct morphs of arctic charr are present: small benthivore, large benthivore, planktivore and piscivore (Sandlund et al., 1987; Jonsson et al., 1988; Skúlason et al., 1989; Snorrason et al., 1989).

Myvatn is the fourth largest lake in Iceland and is found in the northeast $\left(65^{\circ} 35^{\prime} \mathrm{N}, 17^{\circ} 00^{\prime} \mathrm{W}\right)$ at $277.8 \mathrm{~m}$ above sea level (Fig. 1B). It is composed of two basins: the north basin (N-basin, surface area of $8.2 \mathrm{~km}^{2}, 3800$ years old, mean depth of $1.05 \mathrm{~m}$ and a maximum depth of $2.4 \mathrm{~m}$ ) and the south basin (S-basin, surface area of $29.1 \mathrm{~km}^{2}, 2000$ years old, mean depth of $2.3 \mathrm{~m}$ and a maximum depth of $4.2 \mathrm{~m}$ ). The S-basin may also be divided into the central $S$-basin $\left(22 \mathrm{~km}^{2}\right)$ and the east basin (E-basin, $7 \mathrm{~km}^{2}$ ) (Adalsteinsson, 1979a; Olafsson, 1979a). Water inflow to the lake occurs primarily from cold and warm springs (constant flow and temperature) along the eastern shoreline (E-basin). These springs strongly influence the major ion composition and distribution in Myvatn (input loading rates from the springs are $1.4,1.5$ and $340 \mathrm{~g} \cdot \mathrm{m}^{-2} \cdot \mathrm{yr}^{-1}$ for $\mathrm{N}, \mathrm{P}$ and $\mathrm{Si}$ respectively) (Olafsson, 1979b). The formation and present shape of the lake basin are primarily the result of postglacial volcanic activity (Thórarinsson, 1979). Myvatn is a shallow, strongly eutrophic polymictic lake (a nutrient-rich lake that frequently mixes completely). (Jónasson, 1979). Phytoplankton gross production is $118 \mathrm{gC}^{-2} \mathrm{~m}^{-2} \cdot \mathrm{yr}^{-1}$ in the S-basin (1971-76), $75 \mathrm{gC}^{\circ} \mathrm{m}^{-2} \cdot \mathrm{yr}^{-1}$ in the $\mathrm{N}$-basin $(1971-76), 50 \mathrm{gC} \cdot \mathrm{m}^{-2} \cdot \mathrm{yr}^{-1}$ in the E-basin (1972-73) and $5 \mathrm{gC} \cdot \mathrm{m}^{-2} \cdot \mathrm{yr}^{-1}$ near the E-basin springs (Jónasson and Adalsteinsson, 1979). The zooplankton community is again not very diverse (Adalsteinsson, 1979a). The zoobenthos production is quite high but the number of species is limited (Lindegaard, 1979; Lindegaard and Jónasson, 
1979). Three fish species are found in Myvatn: arctic charr, brown trout and the three spine stickleback (Adalsteinsson, 1979b; Kristjansson and Adalsteinsson, 1984).

\section{MATERIALS AND METHODS}

Water samples from the pelagic zone were taken with a Van Dorn type sampler at the water surface and every $10 \mathrm{~m}$ to $70 \mathrm{~m}$ depth in Thingvallavatn (Station T) and at $1 \mathrm{~m}$ intervals in the E- and S-basins of Myvatn (Stations EB and SB, Fig. 1). Three replicate profile samplings were done at each station. Water temperature profiles were also measured during sampling. Turbidity (NTU) was measured in the laboratory within $4 \mathrm{~h}$ of sampling at Thingvallavatn and within $24 \mathrm{~h}$ at Myvatn (Hach Ratio Turbidity meter, Model no. 18900-00). Estimates of the dissolved humic substances or gilvin concentration as $\mathrm{g}_{440}$ (Kirk, 1976) were calculated as $2.303 \mathrm{~A} / 0.1 \mathrm{~m}^{-1}$, where $A$ is the measured absorbance of a membrane-filtered (Whatman GF/C glass fibre and Millipore GS $0.22 \mu \mathrm{m}$ filters) water sample in a $10 \mathrm{~cm}$ cuvette (Varian DMS 90 UV Visible Spectrophotometer). Transparency was measured using a standard Secchi disk at Myvatn.

Underwater depth series of downward and upward irradiances for PAR were measured from $0 \mathrm{~m}$ (just below the water surface) to $10 \mathrm{~m}$ in $1 \mathrm{~m}$ intervals and then to $30 \mathrm{~m}$ in $5 \mathrm{~m}$ intervals in Thingvallavatn on 10 August 1989. In Myvatn they were recorded at $0.5 \mathrm{~m}$ intervals to $2 \mathrm{~m}$ in the E-basin and to $3 \mathrm{~m}$ in the S-basin on 2 August 1989. The instrument used to record irradiance of PAR was a LI-COR LI-185B quantum meter and a LI-192SB underwater quantum sensor. The meter was lowered with an outrigger projecting $75 \mathrm{~cm}$ out into the water over the side of the boat facing the sun, effectively eliminating any boat shadow. Measurements were only conducted under cloudless skies (Myvatn) or when the sun was not obscured by clouds (Thingvallavatn) within $3 \mathrm{~h}$ of solar noon.

Diurnal variation in the downward irradiance of PAR was recorded at $1.5 \mathrm{~m}$ depth at Mjóanes on 20 May, 22 June, 1 August and 23 September 1984. Solar elevations were computed using the method described by Kirk (1983).

From the depth series of PAR, mean upward and downward vertical attenuation coefficients for PAR $\left(\bar{K}_{u}, \bar{K}_{d}\right)$ were calculated by linear regression (Kirk, 1977b). Absolute values for $K_{\mathrm{d}(\mathrm{z})}$, the downward vertical attenuation coefficient at depth (z), were determined for individual depth strata so that changes in broadband $K_{\mathrm{d}}$ values that accompany spectral changes with depth would be accounted for. From these minimum (Min $\left.K_{\mathrm{d}(\mathrm{z})}\right)$, mean $\left(\bar{K}_{\mathrm{d}}\right)$ and maximum $\left(\operatorname{Max} K_{\mathrm{d}(\mathrm{z})}\right)$ values were tabulated for each lake. Reflectance of PAR was calculated as $\mathrm{E}_{\mathrm{u}} \mathrm{E}_{\mathrm{d}}{ }^{-1}$ at any depth (Kirk, 1977b). Euphotic depth, $z_{\mathrm{eu}}$, the depth where incident radiation was reduced to $1 \%$, was determined directly from downward PAR measurements. An estimate of the absorption $(a)$ and scattering $(b)$ coefficients at $z_{\mathrm{m}}$ (the depth where incident radiation was reduced to $10 \%$ ) from upwelling and downwelling values of PAR followed the procedure outlined by Kirk (1981).

The spectral distribution of upwelling and downwelling irradiance $(350-750 \mathrm{~nm})$ was measured at the same depths as PAR using a LI-COR underwater spectroradiometer (Model LI-1800UW/12). The instrument was held rigidly and lowered on the sunny side of the boat about $0.5 \mathrm{~m}$ from the boat's edge. A recording of in-air downward quantum flux (LI-COR LI-185) was taken simultaneously with underwater measurements of downwelling and upwelling irradiance to document variation in incident radiation during the sampling interval. In-air scans of spectral quality were also conducted before and after each downwelling and upwelling series. A scan from 350 to $750 \mathrm{~nm}$ took 35 seconds.

Electroretinogram (ERG)-determined light-adapted spectral sensitivity data for all four adult arctic charr morphs in Thingvallavatn were obtained with permission from Thorarensen (1987). Details of the electrophysiological methods used may be found in his unpublished thesis and in Thorarensen and Einarsson (1985).

\section{RESULTS}

\section{Water and Optical Quality}

Vertical attenuation, absorption and scattering coefficients, gilvin, turbidity and chlorophyll $a$ values were all at least two times greater in Myvatn than they were in Thingvallavatn (Table 1). On the other hand, Secchi disk and euphotic zone depth were much larger in Thingvallavatn, reflecting its much greater transparency. Another difference is evident when the values of Myvatn's east and south basins are compared. This time, all parameters were greater in the S-basin, with the exceptions of Secchi disk and euphotic zone depth.

TABLE 1. Water quality and optical characteristics of Thingvallavatn and Myvatn

\begin{tabular}{|c|c|c|c|}
\hline \multirow[b]{2}{*}{ Parameter } & \multirow[b]{2}{*}{ Thingvallavatn } & \multicolumn{2}{|c|}{ Myvatn } \\
\hline & & S-basin & E-basin \\
\hline Date & 10 August 1989 & 2 August & 1989 \\
\hline $\begin{array}{l}\text { Water temperature } \\
\text { (surface to } \\
\text { bottom, }{ }^{\circ} \mathrm{C} \text { ) }\end{array}$ & $10.5-6.4$ & 10.5 & 8.5 \\
\hline Gilvin, $g_{440}\left(m^{-1}\right)$ & $0.068(0.004,24)^{\mathrm{a}}$ & $0.278(0.007,12)$ & $0.152(0.003,9)$ \\
\hline Turbidity (NTU) & $0.59(0.05,24)$ & $6.8(0.1,12)$ & $2.8(0.11,9)$ \\
\hline Secchi disk (m) & $12-16^{b}$ & 0.5 & 1 \\
\hline $\begin{array}{l}\text { Chlorophyll } a \\
\left(\mu \mathrm{gl}^{-1}\right)\end{array}$ & $0.31(0.05,4)^{b}$ & $18.67(5.21,6)^{c}$ & $9.25(1.25,4)^{\mathrm{c}}$ \\
\hline$a\left(\text { at } z_{\mathrm{m}}, \mathrm{m}^{-1}\right)^{\mathrm{d}}$ & 0.28 & 0.69 & 0.63 \\
\hline$b\left(\text { at } z_{\mathrm{m}}, \mathrm{m}^{-1}\right)^{\mathbf{e}}$ & 0.06 & 9.00 & 4.41 \\
\hline $\operatorname{Max}_{\mathrm{d}(\mathbf{z})}\left(\mathrm{m}^{-1}\right)^{\mathbf{f}}$ & 0.43 & 1.72 & 1.25 \\
\hline $\bar{K}_{\mathrm{d}}\left(\mathrm{m}^{-1}\right) \mathrm{g}$ & 0.14 & 1.47 & 0.71 \\
\hline $\operatorname{Min} K_{\mathrm{d}(\mathrm{z})}\left(\mathrm{m}^{-1}\right)^{\mathrm{h}}$ & 0.03 & 1.24 & 0.33 \\
\hline $\bar{K}_{\mathrm{u}}\left(\mathrm{m}^{-1}\right)^{\mathrm{i}}$ & 0.12 & 1.37 & 0.61 \\
\hline $\begin{array}{l}\text { Euphotic zone } \\
\left(z_{\text {eul }}, m\right)\end{array}$ & 30 & 3.1 & $>3.0$ \\
\hline
\end{tabular}

a Water column mean (standard error, number of samples).

${ }^{b}$ From Snorrason, 1982.

cFrom Jónasson and Adalsteinsson, 1979.

d, eAbsorption (a) and scattering (b) coefficients at the midpoint of the euphotic zone.

$\mathrm{f}, \mathrm{h}$ Maximum and minimum vertical attenuation coefficients for PAR.

g, i Mean downward $\left(\bar{K}_{d}\right)$ and upward $\left(\bar{K}_{\mathrm{u}}\right)$ vertical attenuation coefficients of PAR for the entire water column.

With the exceptions of turbidity at $10 \mathrm{~m}$ and gilvin at $30 \mathrm{~m}$, there is a general increase in these parameters with depth (Fig. 2). Gilvin values begin to plateau after $50 \mathrm{~m}$ depth. Turbidity measurements at 0,20 and $30 \mathrm{~m}$ were significantly lower than 
at $10 \mathrm{~m}(\mathrm{p}<.05, \mathrm{t}$-tests $)$. This higher value at $10 \mathrm{~m}$ coincides with a mild thermocline at this depth. The amount of gilvin at $30 \mathrm{~m}$ was not found to be statistically different from that at either 20 or $40 \mathrm{~m}$ ( $\mathrm{p}>.05$, t-tests).

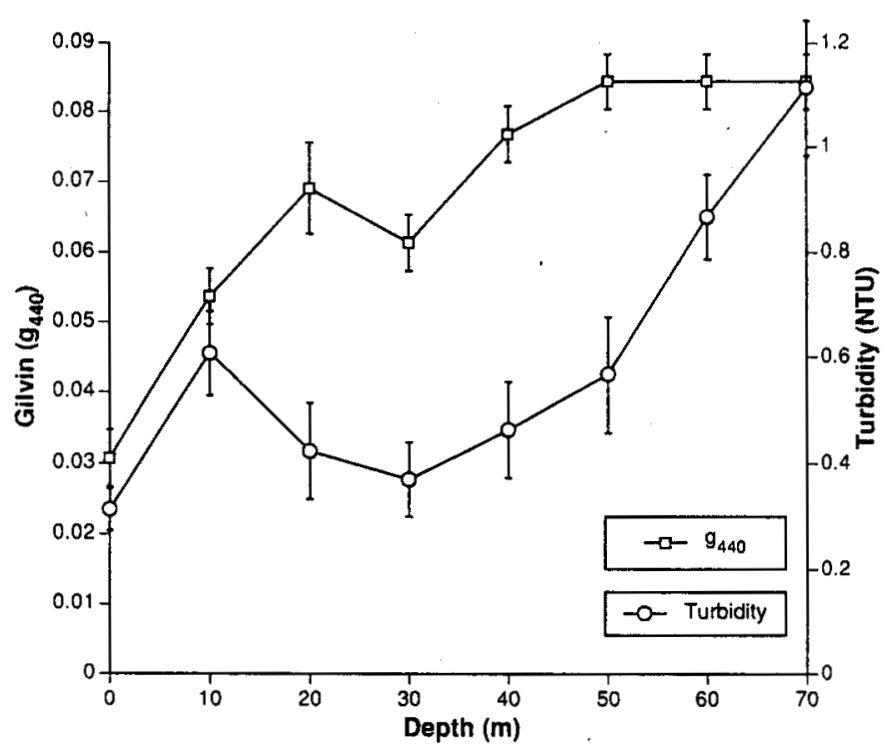

FIG. 2. Turbidity and gilvin depth profiles in Thingvallavatn. Mean values and standard errors at each depth are shown.

Turbidity values in Myvatn were significantly higher at all depths in the S-basin than they were in the E-basin (Fig. 3a, $\mathrm{p}<.01$, t-tests). No significant differences $(p>.05)$ were found with depth but a slight increase was seen at $3 \mathrm{~m}$. These somewhat uniform turbidity levels, as well as isothermic conditions (Table 1), reflect a complete mixing of the water column at the time of sampling. In the E-basin turbidity was significantly higher at $2 \mathrm{~m}$ than at the surface $(p<.05)$. In Figure $3 b$ gilvin values at all depths were also consistently greater in the S-basin $(p<.05$, $\mathrm{t}$-tests). Increases in gilvin with depth were seen in both basins such that in the S-basin measurements at 2 and $3 \mathrm{~m}$ were greater than at 0 and $1 \mathrm{~m}(\mathrm{p}<.05)$ and in the E-basin values at 1 and $2 \mathrm{~m}$ were greater than those at the surface $(\mathrm{p}<.05)$.

Myvatn has higher mean absorption coefficients than Thingvallavatn at all wavelengths measured (Fig. 4). In Myvatn the mean gilvin concentrations (Table 1; Fig. 4) in the S- and E-basins were 4.1 and 2.2 times that found in Thingvallavatn. Small absorption peaks were seen near $700 \mathrm{~nm}$ in all spectra.

\section{Underwater Light}

The curves for downward $\left(E_{d}\right)$ and upward $\left(E_{u}\right)$ irradiance for PAR in Thingvallavatn and Myvatn are approximately linear, in agreement with the exponential manner by which irradiance diminishes with depth in natural waters (Fig. 5). Some departure from this linearity occurs in the upper $2 \mathrm{~m}$ of Thingvallavatn ( $E_{d}$-Thing) and in the upper metre of the east basin of Myvatn $\left(E_{d}-M y E B\right)$. On average upwelling PAR was about 28 times less intense than downwelling PAR in Thingvallavatn. In Myvatn, the same comparison yielded values of 15 and 8 times for the east and south basins respectively. The upwelling and downwelling irradiance values measured at a given depth (Fig. 5) were used to calculate the reflectance of PAR for that depth. No asymptotic state for reflectance was reached in either lake, which is in contrast with that found by Kirk (1977a). Values ranged from $0.041(0 \mathrm{~m})$ to $0.103(25 \mathrm{~m})$ in Thingvallavatn, $0.05(0 \mathrm{~m})$ to $0.08(2.5 \mathrm{~m})$ in the east basin of Myvatn and $0.09(0 \mathrm{~m})$ to $0.145(2.5 \mathrm{~m})$ in the south basin of Myvatn.
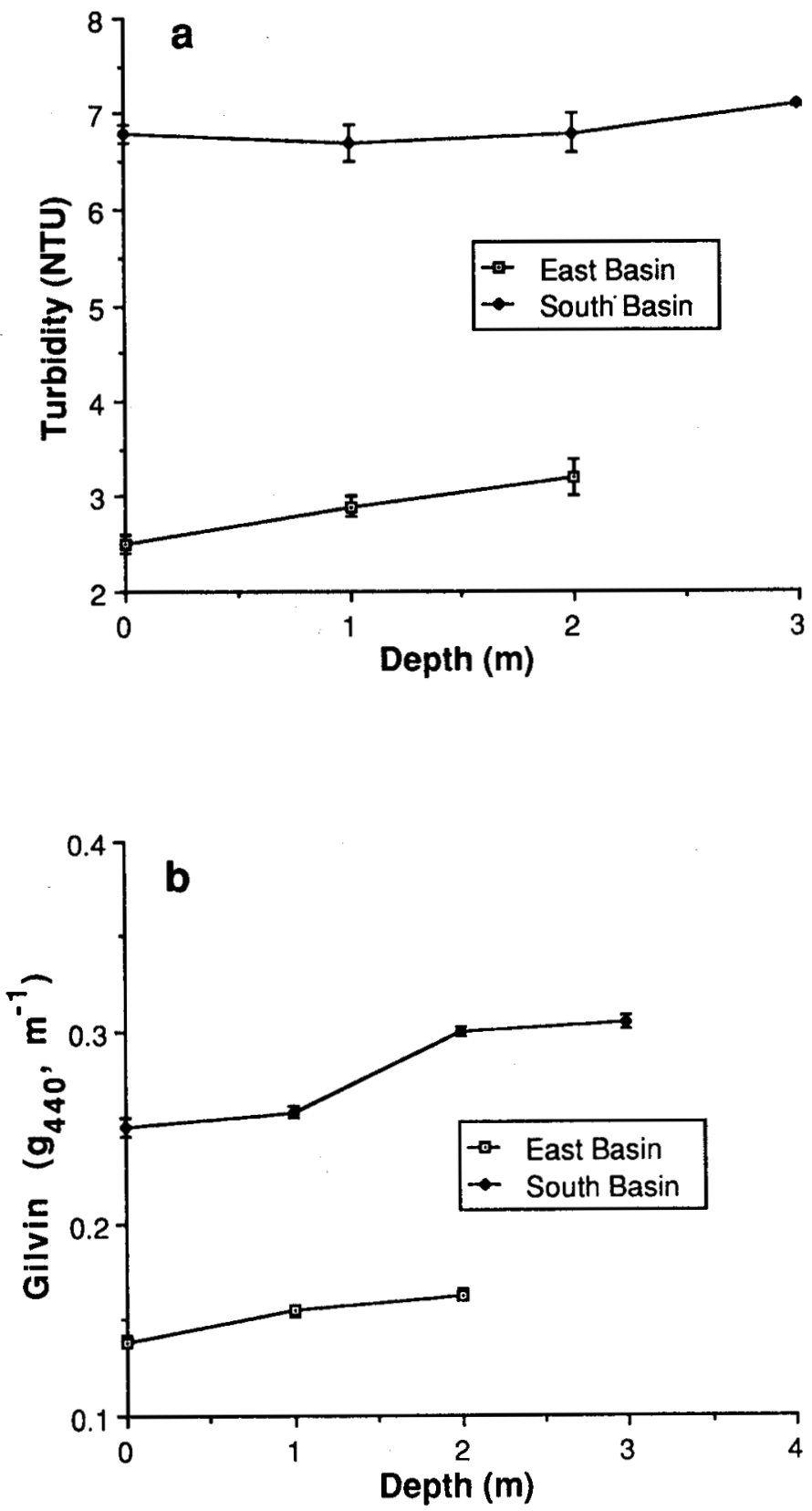

FIG. 3. Turbidity (a) and Gilvin (b) depth profiles in the east and south basins of Myvatn.

The downward irradiance of PAR in Thingvallavatn near Mjóanes exhibits significant diurnal and seasonal variation (Fig. 6). Changing day lengths (Fig. 6) and solar altitudes further illustrate the variation that can occur even at this latitude. Maximum solar heights on 20 May, 22 June, 1 August and 23 September 1984 were $45.9^{\circ}, 49.2^{\circ}, 43.9^{\circ}$ and $25.7^{\circ}$ respectively. Day length and maximum solar height on 2 and 10 August 1989 were $17 \mathrm{~h} 50 \mathrm{~min}, 43.5^{\circ}$ and $16 \mathrm{~h} 57 \mathrm{~min}, 41.3^{\circ}$ respectively. Increases and decreases in irradiance were monotonic except for noticeable changes in measurements at 07:00 and 09:00 (GMT) on 20 May and 10:00 on 23 September, where the sun 
was partially obscured by cloud cover. The greatest incident downward flux occurred at either 11:00 or 12:00 and varied by almost three orders of magnitude over the course of a day. The in-water PAR curves are much narrower than that for the solar irradiance at the top of the atmosphere. This reflects losses resulting from scattering and absorption of the direct and diffuse radiation within the atmosphere.

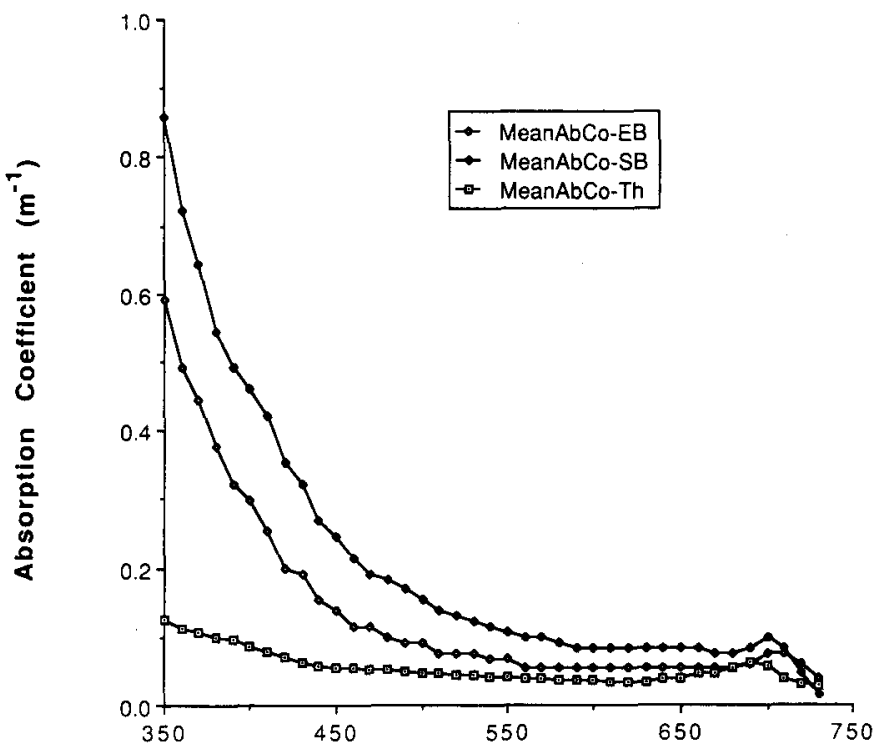

Wavelength $(\mathrm{nm})$

FIG. 4. Mean absorption spectra of dissolved colour (gilvin) in filtered water samples from the entire water columns of Thingvallavatn and Myvatn. MeanAbCo-EB, MeanAbCo-SB and MeanAbCo-Th are mean absorption coefficients for the east and south basins of Myvatn and Thingvallavatn respectively. $\mathrm{n}=\mathbf{8}$ for Thingvallavatn, 3 for the east basin and $\mathbf{4}$ for the south basin. Standard errors were small and are not shown for clarity.

The in-air downward irradiance measurements (Fig. 7a) at Thingvallavatn reveal a number of small irradiance troughs occurring at $430,490,520,690$ and $720 \mathrm{~nm}$. The underwater spectra recorded in Thingvallavatn in the first $2 \mathrm{~m}$ are somewhat variable because of some wave action during the measurement (Fig. 7a). One can see very clearly that wavelengths longer than $600 \mathrm{~nm}$ are rapidly attenuated in the water column (most removed by $4 \mathrm{~m}$ ). This may be attributed to absorption by the water itself (Smith and Baker, 1981; Kirk, 1983). There is less attenuation near the blue end of the spectrum such that more blue than red light remains at $10 \mathrm{~m}$. With increases in depth the band of transmission narrows, such that most of the flux by $10 \mathrm{~m}$ was found between 390 and $600 \mathrm{~nm}$. All of the underwater recordings are unimodal and the wavelength of maximum transmission eventually centres around $510 \mathrm{~nm}$.

The irradiance trough at $520 \mathrm{~nm}$ seen in the in-air spectrum is reflected in all the underwater curves down to a depth of $20 \mathrm{~m}$. Its magnitude delta $E_{\mathrm{d}(\mathrm{z})}(510: 520 \mathrm{~nm})$ decreases exponentially with depth.

Upward irradiance (Fig. 7b) spectra show trends similar to $E_{d}$, as far as the loss of red and blue light is concerned. The width of the transmission zone is, however, narrower than $E_{d}$ in the upper $2 \mathrm{~m}$, but by $10 \mathrm{~m}$ it is very similar to $E_{d}(390-600$ $\mathrm{nm})$. Transmission maxima of the unimodal upward irradiance spectra are located at $480 \mathrm{~nm}$ down to $2 \mathrm{~m}$ depth and then they are shifted to $500 \mathrm{~nm}$ at all other depths. A similar absorption trough was located at $520 \mathrm{~nm}$. Its magnitude delta $\mathrm{E}_{\mathrm{d}(\mathrm{z})}$ $(510: 520 \mathrm{~nm})$ also decreases exponentially with depth. When the size of the trough at each depth was compared with the same parameter in the downwelling spectra, the two were quite well correlated $(r=0.97)$. This provides further evidence for the close relationship between downward and upward irradiance.

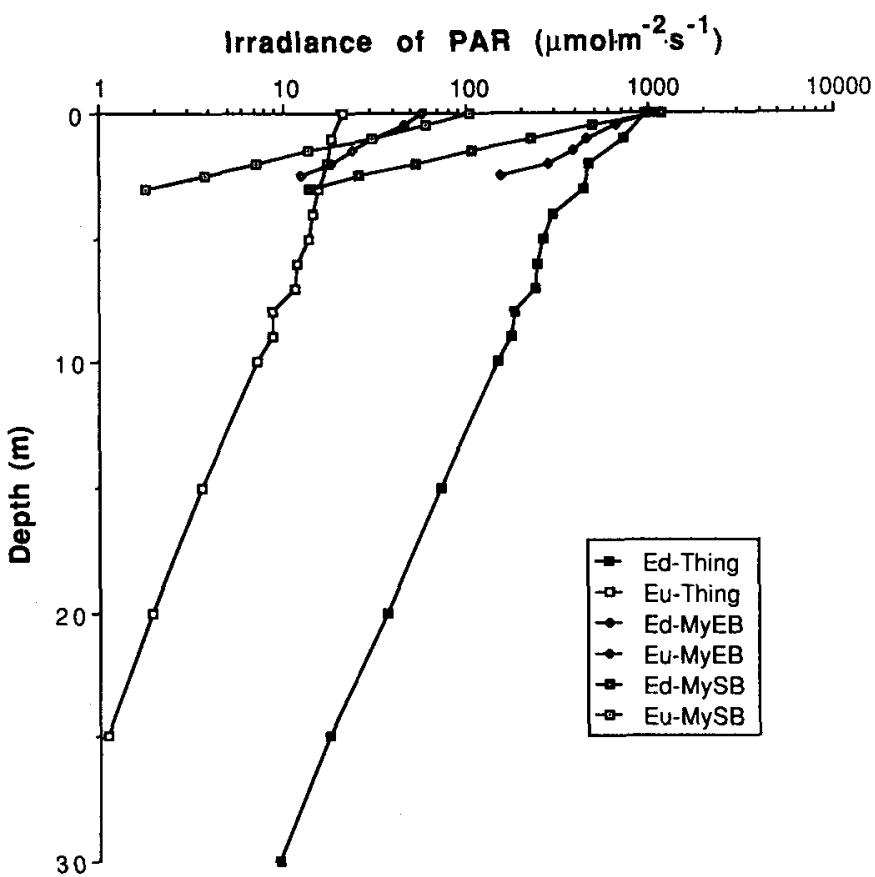

FIG. 5. Attenuation of downward $\left(E_{d}\right)$ and upward $\left(E_{u}\right)$ irradiance of PAR in Thingvallavatn (Thing) and Myvatn (MyEB-east basin, MySB-south basin).

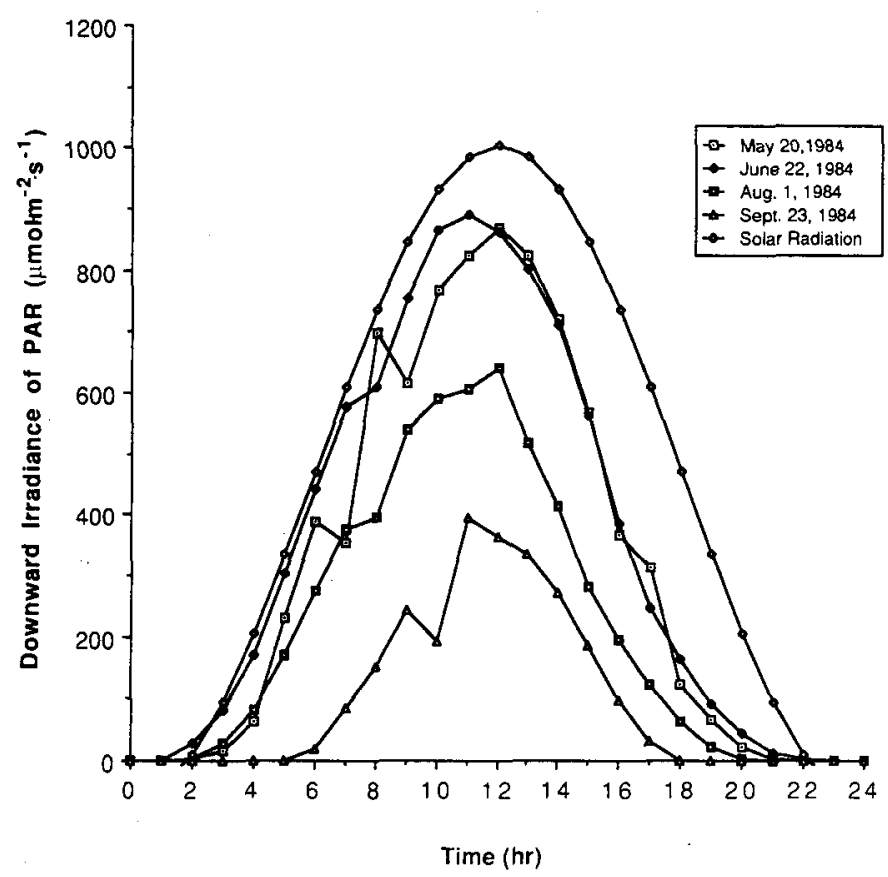

FIG. 6. Diurnal variation in downward irradiance measured at $1.5 \mathrm{~m}$ depth in Thingvallavatn (Mjoanes) on various summer dates. Note the presence of clouds at 07:00 and 09:00 on 20 May and 10:00 on 23 September 1984. The diurnal variation of the solar irradiance in the PAR band, which is incident to the top of the atmosphere at Thingvallavatn, is included for comparison. The recorded value is divided by 2 to facilitate comparison. Local time $=$ GMT. 

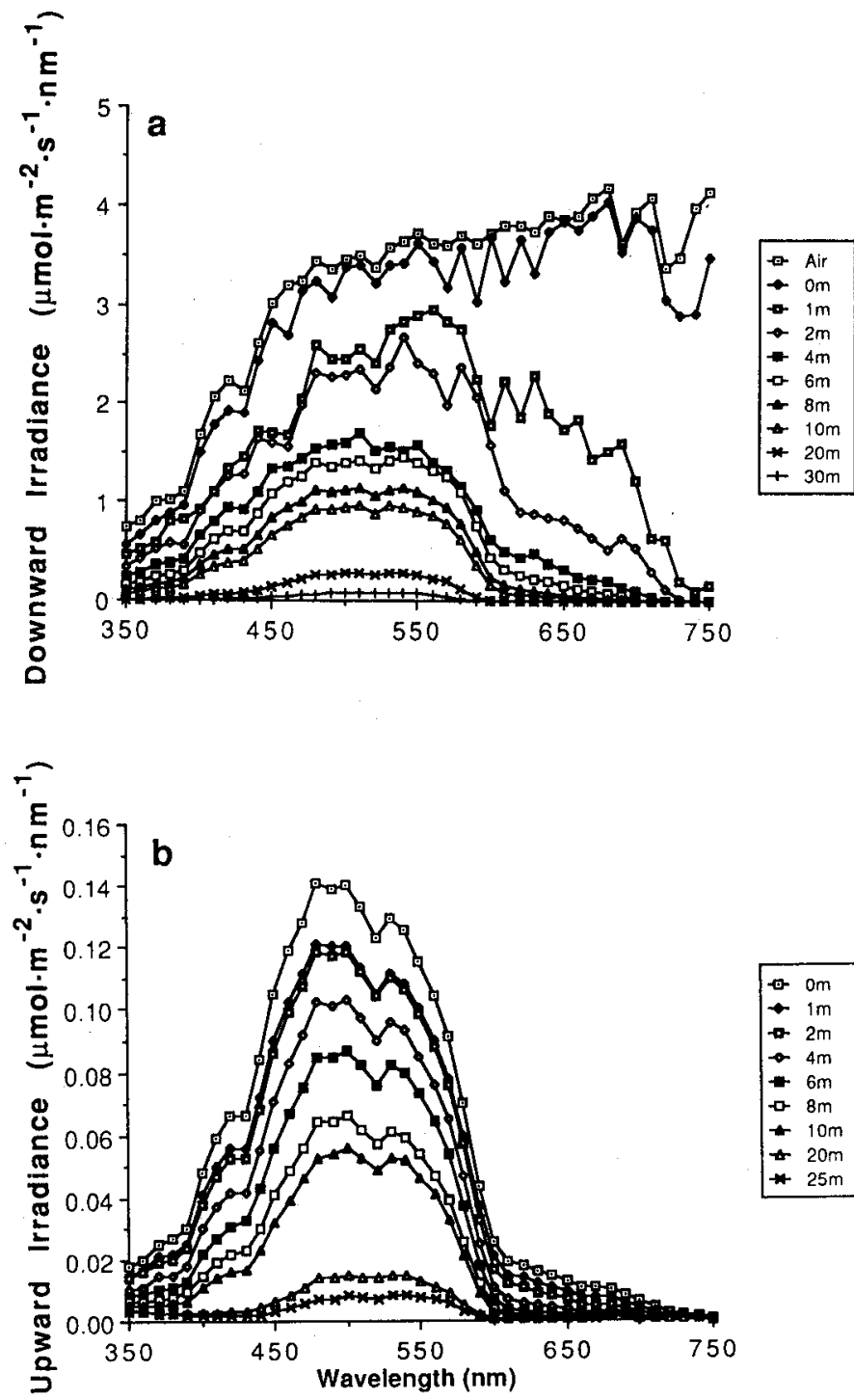

FIG. 7. The spectral distribution of downward (a) and upward (b) irradiance at various depths in Thingvallavatn on 10 August 1989.

The spectral distribution of in-air downward irradiance at the east basin of Myvatn demonstrates the same series of absorption peaks that were observed in Figure 7a. However, these irradiance troughs are not seen in any subsequent underwater measurements (Fig. 8a). Moderate wave action caused the downwelling curves near the surface $(0-1 \mathrm{~m})$ to be quite variable. This subsides between 1 and $2 \mathrm{~m}$, so that they appear unimodal, quite broad $(350-730 \mathrm{~nm})$ and have a maximum transmission near $560 \mathrm{~nm}$. There also is a slightly better transmission of red than blue light. The upwelling irradiance spectra are much less variable (Fig. 8b). They are somewhat trimodal, demonstrating small irradiance troughs that occur near 430,630 and $670-680 \mathrm{~nm}$. The wavelength of maximum transmission is located at or near $\mathbf{5 7 0}$ $\mathrm{nm}$. Upwelling curves appear to be somewhat narrower than downwelling ones $(\sim 50 \mathrm{~nm})$. A better transmission of red compared to blue light is again evident.

Downward irradiance spectra for the south basin of Myvatn, measured at 0 and $0.5 \mathrm{~m}$, are again influenced by wave action, but the characteristic shape of the downwelling light is evident by $1 \mathrm{~m}$ (Fig. 9a). The curves are somewhat trimodal, with maxima occurring at or near 570,650 and $700 \mathrm{~nm}$. Irradiance troughs can be seen near 430,620 and $680 \mathrm{~nm}$. There is also a greater attenuation of blue than red light, and as a result the spectra are narrower than in the east basin.

The upward irradiance curves (Fig. 9b) show troughs and transmission peaks that are similar but more evident than in the east basin. Peaks are again seen near 570,650 and $700 \mathrm{~nm}$, while troughs are found near 430,630 and $680 \mathrm{~nm}$.

The comparison between the spectral distribution of mean downward and upward irradiance measured in Thingvallavatn with spectral sensitivities of adult resident arctic charr morphs highlights several important observations (Fig. 10). Maximum light transmission occurs near $510 \mathrm{~nm}$ for downward irradiance and $500 \mathrm{~nm}$ for upward irradiance. All arctic charr morphs show somewhat similar spectral sensitivity curves. Three of the morphs have their maximum sensitivity near $500 \mathrm{~nm}$, while the large benthivore is most sensitive at $510 \mathrm{~nm}$. The spectral sensitivity of all the arctic charr morphs coincides very well with the spectral quality of light available in the upper $30 \mathrm{~m}$ of Thingvallavatn.
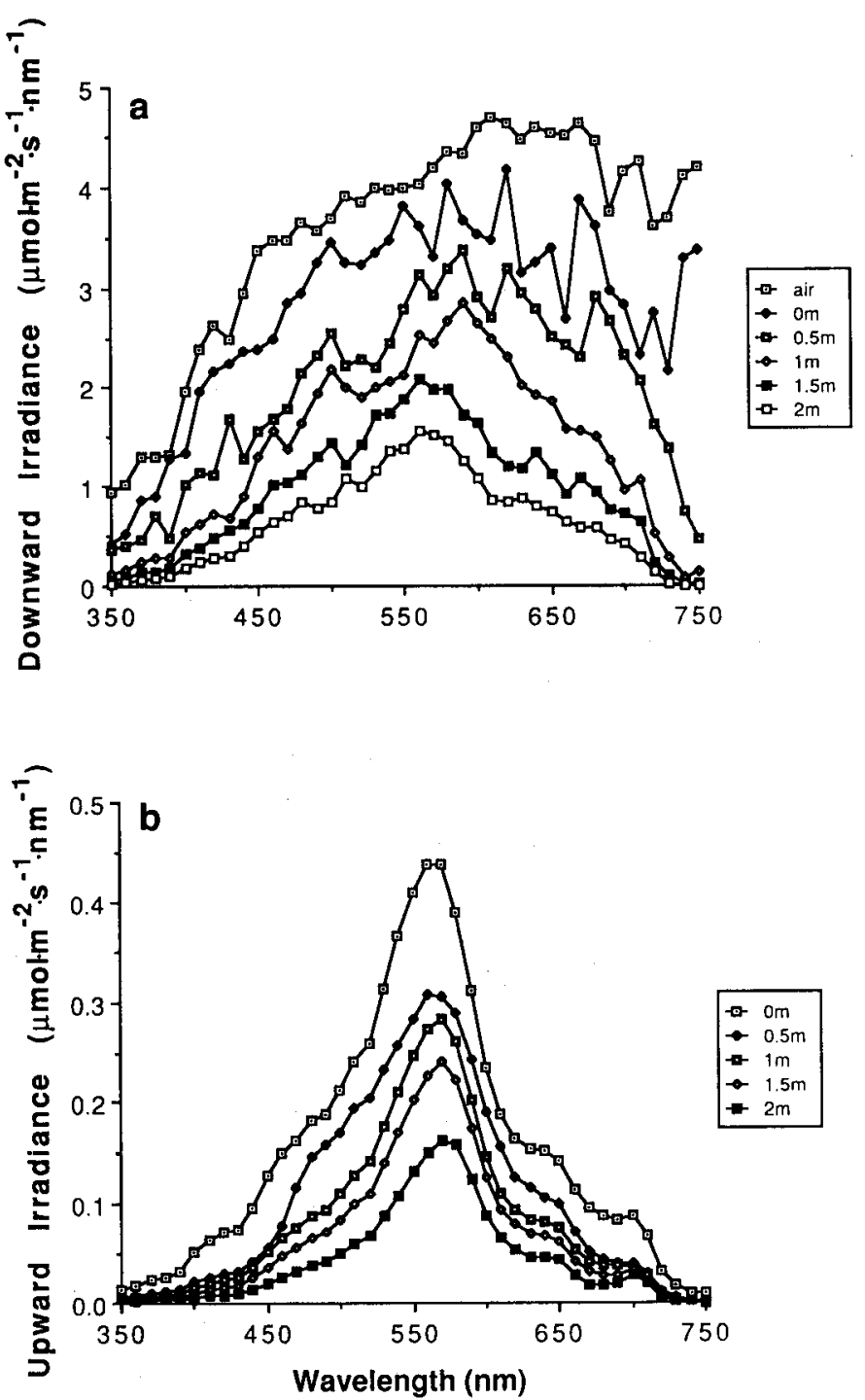

FIG. 8. The spectral distribution of downward (a) and upward (b) irradiance at different depths in the east basin of Myvatn on 2 August 1989. 

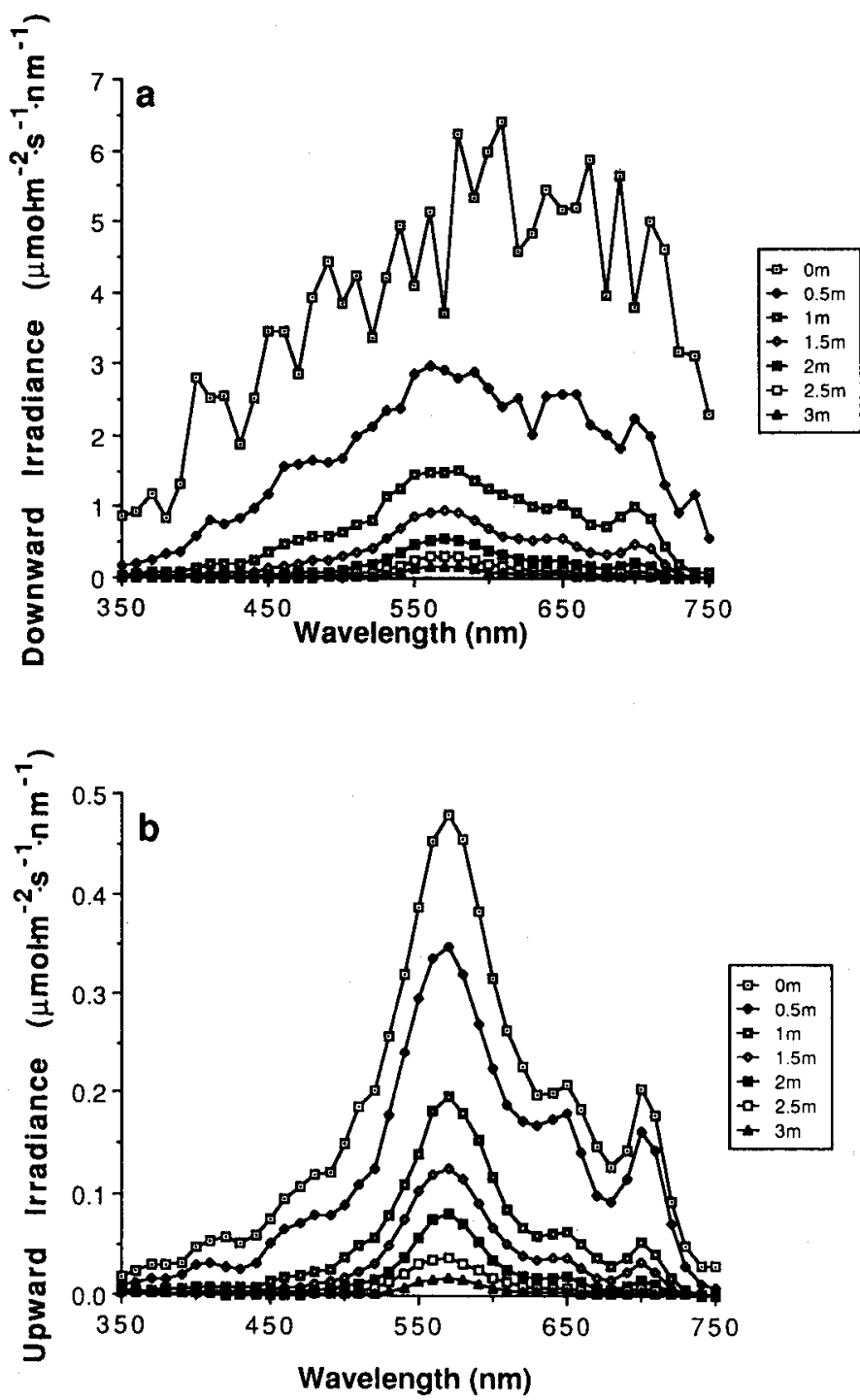

FIG. 9. The spectral distribution of downward (a) and upward (b) irradiance at each depth in the south basin of Myvatn on 2 August 1989.

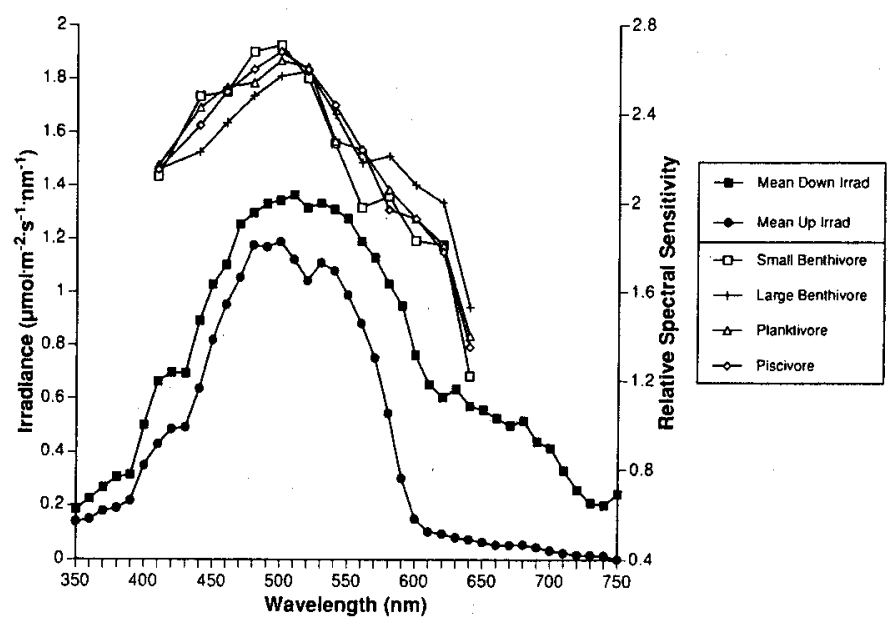

FIG. 10. A comparison between the mean spectral distribution of the downward (upper $30 \mathrm{~m}$ ) and upward (upper $25 \mathrm{~m}$ ) irradiance in Thingvallavatn (this study) and the light-adapted electroretinogram (ERG)-determined spectral sensitivities of adult resident arctic charr morphs (data from Thorarenson, 1987). The upward irradiance has been multiplied by 15 to facilitate comparison.

\section{DISCUSSION}

Water quality and optical parameters (Table 1) measured in Thingvallavatn all confirm the oligotrophic nature of this deep, stable, transparent volcanic/glacial lake. Myvatn, on the other hand, is shown to be a somewhat productive, moderately turbid, shallow volcanic/glacial lake. As a result of its unique array of islands and subterranean inflowing springs, the E-basin may be considered very much less eutrophic, while the productivity and chlorophyll $a$ concentrations of the S-basin evidence the general eutrophic nature of this lake. The productivity of Myvatn is also integrally linked to the regular complete mixing of its water column. Sediments are frequently brought into suspension by prevailing winds, enabling nutrients for phytoplankton and other organisms to be much more available (Jonasson and Adalsteinsson, 1979).

Thingvallavatn is similar in water and optical quality characteristics to two clear, oligotrophic Tasmanian sub-Antarctic and south-temperate lakes (Lakes Prion and Perry respectively). Gilvin $\left(\mathrm{g}_{440}\right)$, turbidity, Secchi disk and $\left(\bar{K}_{\mathrm{d}}\right)$ values reported for Lake Prion were: $0.115 \mathrm{~m}^{-1}, 0.39 \mathrm{NTU}, 11.5 \mathrm{~m}$ and $0.14 \mathrm{~m}^{-1}$ respectively, while those for the glacial Lake Perry were: $0.058 \mathrm{~m}^{-1}, 0.37 \mathrm{NTU}, 15.0 \mathrm{~m}$ and $0.21 \mathrm{~m}^{-1}$ (Bowling et al., 1986). Gilvin values for Thingvallavatn are very low and comparable to those of two Canadian arctic lakes, Little Nauyuk $\left(\mathrm{g}_{440}=0.046\right)$ and Gavia Lake $\left(\mathrm{g}_{440}=0.023\right.$; Heinermann et al. 1990), while much less than some north-temperate shield lakes (Lakes Cromwell and Croche, $\mathrm{g}_{440}=5.56$ and 2.5; Heinermann and Ali, 1988). Though Thingvallavatn may be one of the most transparent lakes in Iceland (S. Skúlason, pers. comm. 1989), its mean downward extinction coefficient $\left(\bar{K}_{\mathrm{d}}\right)$ of $0.14 \mathrm{~m}^{-1}$ is still more than double that of Lake Tahoe $\left(0.06 \mathrm{~m}^{-1}\right)$ and Crater Lake $\left(0.04 \mathrm{~m}^{-1}\right)$, both found in the western United States. Increased gilvin concentrations have shifted its wavelength of maximum downward transmission near $510 \mathrm{~nm}$, compared to 475 and 460 for the latter two lakes, while its euphotic zone $(30 \mathrm{~m})$ is roughly half that of Lake Tahoe $(60 \mathrm{~m})$ and Crater Lake (80 m; Smith et al., 1973).

When the mean absorption spectra of gilvin were measured, a small absorption peak near $700 \mathrm{~nm}$ was observed in all curves (Fig. 4). Since all the samples were filtered, whole algae could not be responsible for these minor peaks. Still, the filtering process may have ruptured cells and released their pigment contents. As a result chlorophyll and its breakdown products could still have an influence upon the absorption spectra of these water samples (French et al., 1972).

Even though the attenuation of downwelling and upwelling irradiance for PAR in Thingvallavatn and in the east basin of Myvatn is mostly exponential (Fig. 5), some departure from this does occur in the upper parts of the water columns. This zone of greater light attenuation may be related to particulates and dissolved substances present. Unfortunately, no gilvin or turbidity samples were taken at these depths. This biphasic characteristic of the downwelling irradiance is common to clearer waters (Kirk, 1983). In more turbid water bodies, exemplified by the south basin of Myvatn, the curve remains quite linear $\left(E_{d}-M y S B\right)$. The higher attenuation coefficients presented in Table 1 for Myvatn are also illustrated by the greater slopes of the curves in Figure 5. The close relationship between the downward and upward flux is clearly demonstrated by the parallel nature of their diminution with depth. 
Marked differences in the attenuation of PAR were seen between the two basins of Myvatn. These may be attributed to the diluting influence of springs entering the east basin. These springs contribute significantly to a reduction in primary productivity within the east basin and a subsequent increase in transparency when compared with the south basin.

The in-air downward irradiance spectra at Thingvallavatn and Myvatn (Figs. 7a, 8a) both show a number of small irradiance troughs at 430,490,520, 690 and $720 \mathrm{~nm}$. These appear to coincide with Fraunhofer lines $G(\mathrm{Fe}$ and $\mathrm{Ca}, 430.8 \mathrm{~nm}), \mathrm{G}^{\prime}$ $(\mathrm{H}, 434.0 \mathrm{~nm}), F(\mathrm{H}, 486.1 \mathrm{~nm}), b_{4}(\mathrm{Fe}$ and $\mathrm{Mg}, 516.8$ and $516.7 \mathrm{~nm}), b_{2}(\mathrm{Mg}, 517.2 \mathrm{~nm}), b_{1}(\mathrm{Mg}, 518.4 \mathrm{~nm}), D_{2}(\mathrm{Na}$, $589.0 \mathrm{~nm}), D_{1}(\mathrm{Na}, 589.6 \mathrm{~nm})$ and $B(\mathrm{O}, 687.0 \mathrm{~nm}$; Weast, 1974). The trough at $720 \mathrm{~nm}$ is not represented by a Fraunhofer line but may be the result of absorption by water vapour in the atmosphere (United States Air Force, 1960). The in-air spectra were similar to those previously recorded in arctic areas (Henriksen et al., 1989) but quite different in terms of spectral distribution from those measured in subarctic regions (Nordtug and Mel $\varnothing, 1988)$. Their measurements at As, Norway $\left(59^{\circ} 40^{\prime}\right)$ show considerably less light in the 500-700 nm range.

The underwater downward irradiance spectral scans near the surface in Thingvallavatn and Myvatn (Figs. 7a, 8a) displayed some variability due to wave action. It has been clearly shown that waves may function as lenses with multiple focal lengths (Schenck, 1957; McFarland and Loew, 1983) and contribute to wide intensity fluctuations in the near surface environment.

The increased blue (blue-green) light penetration (Fig. 7) is linked to the relatively small amount of gilvin present in Thingvallavatn (Table 1). The importance of gilvin in the removal of blue light from the downwelling stream has been observed by many workers (Shapiro, 1957; Kirk, 1976; Verduin, 1982; Kishino et al., 1984; Watras and Baker, 1988; Heinermann and Ali, 1988; Heinermann et al., 1990).

The unusual reflection of the in-air $520 \mathrm{~nm}$ irradiance trough in subsequent underwater spectra (Fig. 7a) deserves some comment. There is a clear exponential decrease of its size with depth. This indicates that no amplification of the trough size has occurred. On the contrary, the processes of absorption and scattering act to erode the size of the trough. The upward-directed fluorescence of organic matter may also contribute to the reduction of this trough (Bristow et al., 1981). This factor may be minimal in importance because of the small amount of organic matter found in Thingvallavatn. As such, after verifying that this was not a result of an instrument error, this trough may be related to Fraunhofer lines $b_{4}, b_{2}$ and $b_{1}$, found near $520 \mathrm{~nm}$.

A comparison of downwelling and upwelling curves (Figs. 7a,b) shows the upwelling ones to be somewhat narrower in the upper $2 \mathrm{~m}$. One would expect the upwelling curves to be not as wide as the downwelling ones because they represent a part of the downward light from a greater depth (i.e., narrower spectral distribution) that has been redirected upwards by scattering (Kirk, 1983). This upward directed light is also more diffuse, resulting in less variability in the spectral distribution curves (Figs. $7 \mathrm{~b}, 8 \mathrm{~b}, 9 \mathrm{~b}$ ).

The downward irradiance recordings in Myvatn were all quite broad, with a maximum transmission occurring at $560 \mathrm{~nm}$ in the east basin and $570 \mathrm{~nm}$ in the south basin (Figs. 8a, 9a). East basin spectra were unimodal, while those in the south basin were trimodal. Gilvin plays an important role in the reduction of wavelengths less than $500 \mathrm{~nm}$, while the absorption of wavelengths longer than $600 \mathrm{~nm}$ can be attributed to the water itself acting in conjunction with chlorophyll concentrations present. These effects are somewhat limited because of the shallow nature of this lake.

The trimodal nature of the upwelling curves (Figs. $8 \mathrm{~b}, 9 \mathrm{~b}$ ) in both basins can be directly linked to the chlorophyll $a$ and algae present. The predominant alga found in the east and south basins at the time of measurement was Anabaena flos-aquae, a blue-green alga containing chlorophyll $a$. In vivo absorption measurements of another blue-green Synechococcus leopoliensis have demonstrated absorption maxima of 440,625 and $680 \mathrm{~nm}$ (Doucha and Kubin, 1976). These coincide reasonably well with absorption troughs in this study and with chlorophyll $a$ absorption maxima in diethyl ether at 430, 615 and $662 \mathrm{~nm}$ (Kost, 1988). Chlorophyll $a$ has been shown in living cells to have its broad absorption in the red shifted to a maximum of $676 \mathrm{~nm}$ (Kirk, 1983; Davies-Colley et al., 1986).

This comprehensive analysis of the underwater photic environments of Thingvallavatn and Myvatn provides useful information that may be integrated with the existing and future ecological studies in these ridge lakes. As well, it forms the basis for further comparisons with data gathered by remote sensing techniques in this region.

Information regarding the visual abilities of the arctic charr in Myvatn is not available but some data do exist for those in Thingvallavatn. The light-adapted ERG-determined spectral sensitivity curves of arctic charr in Thingvallavatn (Fig. 10) show a maximum sensitivity near $500 \mathrm{~nm}$, which may be the result of an interaction between blue and green cone receptors in the eye (Thorarensen and Einarsson, 1985; Thorarensen, 1987). They also found their dark-adapted spectral sensitivity measurements to be similar in form and maxima. This was attributed to the absorption of a visual pigment (rhodopsin) with a maximum absorption $\left(\lambda_{\max }\right)$ of $509 \mathrm{~nm}$ (Munz and Beatty, 1965; Munz and McFarland, 1965). In these studies no concurrent measurements of the underwater light fields were made. Other studies on fish have also demonstrated this close matching between ERG-recorded spectral sensitivities and visual pigment absorption maxima (Douglas, 1983; Pankhurst and Montgomery, 1989). Douglas (1983) found in the rainbow trout that the lightadapted spectral sensitivity curve provided a good match with hypothetical blue $\left(\lambda_{\max }=440 \mathrm{~nm}\right)$ and green $\left(\lambda_{\max }=535 \mathrm{~nm}\right)$ cone pigments. He did not observe any interaction between these two receptors, nor did he measure underwater light.

Few studies have attempted a direct comparison between the quality of the underwater light and the spectral sensitivity or visual pigment absorption of resident fish (Heinermann and Ali, 1985; Crescitelli et al., 1985; Pankhurst and Montgomery, 1989; Heinermann and Ali, 1989). In the first three of these works and this study a good correspondence was found between the underwater light and the visual sensitivity of the fish. Our findings provide support for the sensitivity hypothesis. It states that fish visual pigments have their $\lambda_{\max }$ at wavelengths that are most abundant in the underwater environment (Munz, 1965) to optimize quantal catch and, consequently, maximize visual sensitivity. According to this proposal, objects in deep water, objects viewed at a distance and objects darker than the background space light would be most effectively detected by a pigment whose spectral absorbance matches the colour of the background. The advantage of this kind of adaptation for the arctic charr in Thingvallavatn may be directly linked to their feeding ecology. 
Both the large and small benthivores feed heavily under low light situations (at dusk and at night) on a pulmonate gastropod Lymnaea peregra, while the small benthivore frequently includes chironomid larvae and pupae in its diet (Malmquist et al., 1985; Sandlund et al., 1987). These prey are often seen against the bottom itself and frequently would appear darker than it. In these cases having a spectral sensitivity matched to the ambient light would be a very efficient adaptation. The planktivore feeds largely at dusk on zooplankton (Cyclops abyssorum and Daphnia longispina) and some chironomid pupae. The zooplankton is relatively transparent, except for dark eye spots and their digestive system, so visual detection from a distance would be difficult. Their jerky movement in conjunction with the dark eye spot could render them visible. For this morph movement detection may be more important than sensitivity matching. Piscivorous charr feed almost exclusively on three spined sticklebacks. These prey may often be seen at a distance and at times, depending upon the angle of view, would appear darker than the ambient spacelight. Again, matching its sensitivity to the background light would be a more effective strategy. It appears that for at least three of the four arctic charr morphs, having a spectral sensitivity matched to the underwater light field would be a distinct advantage in their feeding strategies.

\section{CONCLUSIONS}

The underwater light fields of Thingvallavatn and Myvatn are quite different in terms of both the quantity and quality of light present. The amount of chlorophyll $a$, gilvin and turbidity, which are to some degree a reflexion of trophic state, all make important contributions to these modifications. As a result the deep, oligotrophic Thingvallavatn has a distinctive blue to bluish-green appearance, while the shallow, eutrophic Myvatn appears green to greenish-yellow. Differences in light transmission between the east and south basins of Myvatn appear to be strongly influenced by springs entering the east basin. The importance of phytoplankton (chlorophyll) in modifying the underwater light climate of Myvatn is clearly demonstrated. In addition, the mean downwelling and upwelling irradiance spectra in Thingvallavatn coincide very well with the light-adapted spectral sensitivities of the resident arctic charr. This has important consequences for the feeding ecology of these fish. These data present a quantitative and qualitative description of the underwater light fields of Thingvallavatn and Myvatn and indicate that Thingvallavatn's charr have adapted to maximize photon capture in support of the sensitivity hypothesis.

\section{ACKNOWLEDGEMENTS}

We thank Jean François St. Pierre and Marcel Babin, of Environment Canada, and Dr. Ellis Loew for the loan of the two underwater spectroradiometers used in this study. We are especially thankful to Skúli Skúlason for his contribution to the organization, logistics and execution of the sampling program at both Thingvallavatn and Myvatn. We are grateful to S. Snorrasson and H. Malmquist for their valuable discussions and field assistance at Thingvallavatn. Our appreciation is also extended to Dr. G. Renninger and Dr. A. Mayumdar for their critical revisions of this manuscript. Financial support for this research was provided by NSERC to M.A. Ali.

\section{REFERENCES}

ADALSTEINSSON, H. 1979a. Zooplankton and its relation to available food in Lake Myvatn. Oikos 32:162-194. 1979b. Size and food of arctic char Salvelinus alpinus and stickleback Gasterosteus aculeatus in Lake Myvatn. Oikos 32:228-231.

ANTONSSON, U. 1977. Zooplankton of lake Thingvallavatn 1972-75. Postgraduate thesis, University of Iceland, Reykjavik, Iceland. (In Icelandic.)

ARNASON, B. 1976. Groundwater systems in Iceland traced by deuterium. Societas Scientiarum Islandica 42:1-236.

BARLOW, G.W. 1974. Contrasts in social behaviour between central American cichlid fishes and coral-reef surgeon fishes. American Zoologist 14:9-34.

BOWLING, L.C., STEANE, M.S., and TYLER, P.A. 1986. The spectral distribution and attenuation of underwater irradiance in Tasmanian inland waters. Freshwater Biology 16:313-335.

BRISTOW, M., NIELSEN, D., BUNDY, D., and FURTEK, R. 1981. Use of water Raman emission to correct airborne laser fluorosensor data for effects of water optical attenuation. Applied Optics 20:2889-2906.

CHAMBERS, P.C., and PREPAS, E.E. 1988. Underwater spectral attenuation and its effect on the maximum depth of angiosperm colonization. Canadian Journal of Fisheries and Aquatic Sciences 45:1010-1017.

CRESCITELLI, F., McFALL-NGAI, M., and HORWTTZ, J. 1985. The visual pigment sensitivity hypothesis: Further evidence from fishes of varying habitats. Journal of Comparative Physiology A 157:323-333.

DABROWSKI, K.R., and JEWSON, D.H. 1984. The influence of light environment on depth of visual feeding by larvae and fry of Coregonus pollan (Thompson) in Lough Neagh. Journal of Fish Biology 25:173-181.

DAVIES-COLLEY, R.J., PRIDMORE, R.D., and HEWTTT, J.E. 1986. Optical properties of some freshwater phytoplanktonic algae. Hydrobiologia 133:165-178.

DOUGLAS, R.H. 1983. Spectral sensitivity of rainbow trout (Salmo gairdneri). Revue Canadienne de Biologie Experimentale 42:117-122.

DOUCHA, J., and KUBIN, S. 1976. Measurement of in vivo absorption spectra of microscopic algae using bleached cells as a reference sample. Archiv für Hydrobiologie 49:199-213.

DUBINSKY, Z., and BERMAN, T. 1979. Seasonal changes in the spectral composition of downwelling irradiance in Lake Kinneret (Israel). Limnology and Oceanography 24:655-663.

ELORANTA, P. 1978. Light penetration in different types of lakes in central Finland. Holarctic Ecology 1:362-366.

FRENCH, C.S., BROWN, J.S., and LAWRENCE, M.C. 1972. Four universal forms of chlorophyll $a$. Plant Physiology 49:421-429.

GARDARSSON, A., GISLASON, G.M., and EINARSSON, A. 1988. Long term changes in the lake Myvatn ecosystem. Aqua Fennica 18:125-135.

GUTHRIE, D.M. 1986. Role of vision in fish behaviour. In: Pitcher, T.J., ed. The behaviour of teleost fishes. London: Croom Helm. 75-113.

HEINERMANN, P.H. 1986. The photic environment and scotopic visual pigments: A historical review and experimental approach using Semotilus atromaculatus, Catostomus commersoni and Exoglossum maxillingua. M. Sc. thesis, Université de Montreal, Montreal, Quebec.

HEINERMANN, P.H., and ALI, M.A. 1985. Correlation between the photic environment and porphyropsin in the cutlips minnow, Exoglossum maxillingua. Naturwissenschaften 72:488-489.

HEINERMANN, P.H., and ALI, M.A. 1988. Seasonal changes in the underwater light climate of two Canadian shield lakes. Hydrobiologia 169:107-121.

HEINERMANN, P.H., and ALI, M.A. 1989. The photic environment and scotopic visual pigments of the creek chub, Semotilus atromaculatus and white sucker, Catostomus commersoni. Journal of Comparative Physiology A 164:707-716.

HEINERMANN, P.H., JOHNSON, L., and ALI, M.A. 1990. The underwater photic environment of a small arctic lake. Arctic 43:129-136.

HENRIKSEN, K., STAMNES, K., and ØSTENSEN, P. 1989. Measurements of solar u.v., visible and near i.r. irradiance at $78^{\circ} \mathrm{N}$. Atmospheric Environment 23:1573-1579.

JEFFREY, S.W. 1980. Algal pigment systems. In: Falkowski, P.G., ed. Primary productivity in the sea. New York: Plenum Press. 33-58.

JONSSON, B., SKÚLASON, S., SNORRASON, S.S., SANDLUND, O.T., MALMQUIST, H.J., JÓNASSON, P.M., GYDEMO, R., and LINDEM, T. 1988. Life history variation of polymorphic arctic charr (Salvelinus alpinus) in Thingvallavatn, Iceland. Canadian Journal of Fisheries and Aquatic Sciences 45:1537-1547.

JONSSON, G.S. 1987. The depth-distribution and biomass of epilithic periphyton in lake Thingvallavatn, Iceland. Archiv für Hydrobiologie 108:531-547.

JONASSON, P.M. 1979. The lake Myvatn ecosystem, Iceland. Oikos 32:289-305.

JONASSON, P.M., and ADALSTEINSSON, H. 1979. Phytoplankton production in shallow eutrophic Lake Myvatn, Iceland. Oikos 32:113-138.

JÓNASSON, P.M., and LINDEGAARD, C. 1988. Ecosystem studies of North Atlantic ridge lakes. Verhandlungen der Internationale Vereinigung für Theoretische und Angewandte Limnologie 23:394-402. 
KAIRESALO, T., JÓNSSON, G.S., GUNNARSSON, K., and JÓNASSON, P.M. 1989. Macro- and microalgal production within a Nitella opaca bed in Lake Thingvallavatn, Iceland. Journal of Ecology 77:332-342.

KIRK, J.T.O. 1976. Yellow substance (Gelbstoff) and its contribution to the attenuation of photosynthetically active radiation in some inland and coastal south-eastern Australian waters. Australian Journal of Marine and Freshwater Research 27:61-71.

1977a. Attenuation of light in natural water. Australian Journal of Marine and Freshwater Research 28:497-508.

$1977 \mathrm{~b}$. Use of a quanta meter to measure attenuation and underwater reflectance of photosynthetically active radiation in some inland and coastal south-eastern Australian waters. Australian Journal of Marine and Freshwater Research 28:9-21.

1979. Spectral distribution of photosynthetically active radiation in some southeastern Australian waters. Australian Journal of Marine and Freshwater Research 30:81-91.

1980. Spectral absorption properties of natural waters: Contribution of the soluble and particulate fractions to light absorption in some inland waters of southeastern Australia. Australian Journal of Marine and Freshwater Research 31:287-296.

1981. Estimation of the scattering coefficient of natural water using underwater irradiance measurements. Australian Journal of Marine and Freshwater Research 32:533-539.

1983. Light and photosynthesis in aquatic ecosystems. Cambridge, MA: Cambridge University Press.

. 1985. Effects of suspensoids (turbidity) on penetration of solar radiation in aquatic systems. Hydrobiologia 125:195-208.

. 1989. The upwelling light stream in natural waters. Limnology and Oceanography 34:1410-1425.

KISHINO, M., BOOTH, C.R., and OKAMI, N. 1984. Underwater radiant energy absorbed by phytoplankton, detritus, dissolved organic matter and pure water. Limnology and Oceanography 29:340-349.

KOST, H.P., ed. 1988. Plant pigments (CRC handbook of chromatography). Boca Raton: CRC Press.

KRISTJANSSON, J., and ADALSTEINSSON, H. 1984. The ecology and management of the arctic charr Salvelinus alpinus in Lake Myvatn, North Iceland. In: Johnson, L., and Burns, B., eds. Biology of the arctic charr. Winnipeg: University of Manitoba Press. 341-347.

LASTEIN, E. 1983. Decomposition and sedimentation processes in oligotrophic subarctic Lake Thingvalla, Iceland. Oikos 40:103-112.

LEVINE, J.S., LOBEL, P.S., and MacNICHOL, E.F. 1980. Visual communication in fishes. In: Ali, M.A., ed. Environmental physiology of fishes. New York: Plenum Press. 447-475.

LINDEGAARD, C. 1979. The invertebrate fauna of Lake Myvatn. Oikos 32:151-161.

1980. Bathymetric distribution of Chironomidae (Diptera) in the oligotrophic lake Thingvallavatn, Iceland. In: Murray, D.A., ed. Chironomidae, ecology, systematics, cytology and physiology. New York: Pergamon Press. 225-232.

LINDEGAARD, C., and JÓNASSON, P.M. 1979. Abundance, population dynamics and production of zoobenthos in Lake Myvatn, Iceland. Oikos 32:202-227.

LYTHGOE, J.N. 1979. The ecology of vision. Oxford: Clarendon Press. 1987. Light and vision in the aquatic environment. In: Atema, J., Fay, R.R., Popper, A.N., and Tavolga, W.N., eds. Sensory biology of aquatic animals. New York: Springer-Verlag. 57-82.

MALMQUIST, H.J., SNORRASON, S.S., and SKÚLASON, S. 1985. The biology of arctic charr (Salvelinus alpinus [L.]) in Lake Thingvallavatn, Iceland. I. Feeding ecology. Náttúrufrae dinguriunn 55:195-217. (In Icelandic, with English summary.)

McFARLAND, W.N., and LOEW, E.R. 1983. Wave-produced changes in underwater light and their relations to vision. Environmental Biology of Fishes 8:173-184.

McFARLAND, W.N., and MUNZ, F.W. 1975. Part II: The photic environment of clear tropical seas during the day. Vision Research 15:1063-1070.

MUNK, P., KIØRBOE, T., and CHRISTENSEN, V. 1989. Vertical migrations of herring, Clupea harengus, larvae in relation to light and prey distribution. Environmental Biology of Fishes 26:87-96.

MUNZ, F.W. 1965. Adaptation of visual pigments to the photic environment. In: Reuck, A.V.S., and Knight, J., eds. Color vision: Physiology and experimental psychology. London: $J$ and A Churchill. 27-45.
MUNZ, F.W., and BEATTY, D.D. 1965. A critical analysis of the visual pigments of salmon and trout. Vision Research 5:1-17.

MUNZ, F.W., and McFARLAND, W.L. 1965. A suggested hereditary mechanism for visual pigments of chars (Salvelinus spp.). Nature 206:955-956.

NORDTUG, T., and MEL $\emptyset$, T.B. 1988. Diumal variations in natural light conditions at summer time in arctic and subarctic areas in relation to light detection in insects. Holarctic Ecology 11:202-209.

OLAFSSON, J. 1979a. Physical characteristics of Lake Myvatn and River Laxa. Oikos 32:38-66. 32:82-112.

PANKHURST, N.W., and MONTGOMERY, J.C. 1989. Visual function in four Antarctic Nototheniid fishes. Journal of Experimental Biology 142:311-324.

RINGELBERG, J. 1964. The positively phototactic reaction of Daphnia magna Straus: A contribution to the understanding of diurnal vertical migration. Netherlands Journal of Sea Research 2:319-406.

RIST, S. 1975. Stöduvötn, Endurskodud útgáfa. (Lakes in Iceland.) Reykjavik: OSROD 7519. (In Icelandic.)

ROEMER, S.C., and HOAGLAND, K.D. 1979. Seasonal attenuation of quantum irradiance (400-700 nm) in three Nebraska reservoirs. Hydrobiologia 63:81-92.

SAEMUNDSSON, K. 1976. Vulcanismus und tectonik des Hengill-gegietes in Sudvest Island. Acta Naturalia Islandica 2:1-51.

SANDLUND, O.T., JONSSON, B., MALMQUIST, H.J., GYDEMO, R., LINDEM, T., SKÚLASON, S., SNORRASON, S.S., and JÓNASSON, P.M. 1987. Habitat use of arctic charr Salvelinus alpinus in Thingvallavatn, Iceland. Environmental Biology of Fishes 20:263-274.

SCHENCK, H. 1957. On the focusing of sunlight by ocean waves. Journal of the Optical Society of America 47:653-657.

SHAPIRO, J. 1957. Chemical and biological studies on the yellow organic acids of lake water. Limnology and Oceanography 2:161-179.

SIEBECK, O. 1960. Untersuchungen über die Vertikalwanderung planktischer Crustaceen unter Berücksichtigung der Strahlungsverhältnisse. Internationale Revue der Gesamten Hydrobiologie 45:381-454.

SKÚLASON, S., NOAKES, D.L.G., and SNORRASON, S.S. 1989. Ontogeny of trophic morphology in four sympatric morphs of arctic charr Salvelinus alpinus in Thingvallavatn, Iceland. Biological Journal of the Linnean Society 38:281-301.

SMITH, R.C., and BAKER, K.S. 1981. Optical properties of the clearest natural waters (200-800 nm). Applied Optics 20:177-184.

SMITH, R.C., TYLER, J.E., and GOLDMAN, C.R. 1973. Optical properties and color of Lake Tahoe and Crater Lake. Limnology and Oceanography 18:189-199.

SNORRASON, S.S. 1982. The littoral ecosystem and the ecology of Limnea peregra in Lake Thingvallavatn, Iceland. Ph.D. thesis, University of Liverpool, Liverpool, England.

SNORRASON, S.S., SKÚLASON, S., SANDLUND, O.T., MALMQUIST, H.J., JONSSON, B., and JÓNASSON, P.M. 1989. Shape polymorphism in arctic charr, Salvelinus alpinus, in Thingvallavatn, Iceland. Physiological Ecology of Japan 1:393-404.

TALLING, J.F. 1971. The underwater light climate as a controlling factor in the production ecology of freshwater phytoplankton. Mitteilungen Internationale Vereinigung für Theoretische und Angewandte Limnologie 19:214-243.

THORARENSEN, H.T. 1987. Spectral sensitivity of four morphs of arctic charr (Salvelinus alpinus [L.]) (Pisces: Salmonidae) in Thingvallavatn. Undergraduate thesis, University of Iceland, Reykjavik. 62 p.

THORARENSEN, H.T., and EINARSSON, G. 1985. ERG measurements of spectral sensitivity in two types of arctic charr (Salvelinus alpinus [L.]). Acta Physiologica Scandinavia 124(542):253.

THÓRARINSSON, S. 1979. The postglacial history of the Myvatn area. Oikos 32:17-28.

UNITED STATES AIR FORCE. Geophysics Research Directorate. 1960. Handbook of geophysics. New York: Macmillan.

VERDUIN, J. 1982. Components contributing to light extinction in natural waters: Method of isolation. Archiv für Hydrobiologie 93:303-312.

WATRAS, C.J., and BAKER, A.L. 1988. The spectral distribution of downwelling light in northern Wisconsin lakes. Archiv für Hydrobiologie 112:481-494.

WEAST, R.C., ed. 1974. CRC handbook of chemistry and physics. Cleveland: CRC Press. 